\title{
Electoral integrity, voter fraud and voter ID in polling stations: lessons from English local elections
}

\begin{abstract}
Polling stations are at the fulcrum of the democratic process. They are the location where most voters exercise their democratic rights, but also one place where electoral fraud and irregularities may occur, both in consolidating and established democracies. This study provides a detailed analysis of the nature and frequency of electoral irregularities that are found in English local elections using original surveys of poll workers in 2018 and $2019(n=5659)$. It also identifies the effects of recent attempts to improve electoral integrity through the introduction of voter identification requirements on a pilot basis. Elections are found to be broadly well run but problems are reported with names missing from the electoral register and polling station accessibility requirements. Some more infrequent problems were reported with inappropriate behaviour from party agents/candidate - and some gender-based intimidation amongst voters. Attempted impersonation was exceptionally rare, however, and measures to introduce voter identification requirements therefore had little effect on the security of the electoral process. In fact, they led to some voters not casting their ballot, either for reasons of convenience and availability of suitable forms of ID, or reasons of principle and protest. There are therefore important implications for the wider literature on electoral integrity and the design of democratic practices.
\end{abstract}

Professor Toby S. James, School of Politics, Language and Communication Studies, University of East Anglia, Norwich, UK.

Dr. Alistair Clark, School of Politics, Geography and Sociology, Newcastle University, UK.

Professor Toby S. James is Professor of Politics and Public Policy at the University of East Anglia. He has published widely on electoral integrity, political leadership and the policy process. Books include Elite Statecraft and Election Administration (2012, Palgrave) and Comparative Electoral Management (2020). He is co-convenor of the global Electoral Management Network and tweets @tobysjames.

Dr. Alistair Clark is Reader in Politics at Newcastle University, UK. His research focuses on electoral integrity and administration, political parties and parliament. His work has been published in leading international journals, and he is the author of Political Parties in the UK (Palgrave), now in its second edition. He tweets at @ClarkAlistairJ. 


\section{Introduction}

Polling stations are at the fulcrum of the democratic process. They are the location where most voters exercise their democratic right by casting their vote and therefore have an iconic and symbolic place within democratic practices. They are also the location where electoral fraud and irregularities are thought to occur, both in consolidating and established democracies. These irregularities might include outright attempts to rig the electoral process through ballot box stuffing, carousel voting and voter intimidation (Schedler 2002). They might also involve bureaucratic hurdles that makes voting more difficult than it otherwise needs to be. Practice and procedure could also more heavily disadvantage some individuals or groups of voters more than others if polling practices are not inclusive (James and Garnett, this issue). For example, polling stations might lack accessibility requirements (Schur, Ameri, and Adya 2017) or onerous voter identification requirements might exist (Burden 2018).

The extent and nature of these irregularities are commonly subject to speculation. Evidence about the frequency of them is less common, however. This study provides a detailed analysis of the nature and frequency of electoral irregularities that are reported in English local elections using original surveys of poll workers in 2018 and 2019 ( $n=5659)$. It also identifies the implications of recent attempts to improve electoral integrity through the introduction of voter identification requirements on a pilot basis in a selection of local government areas. This was the first time that voter identification requirements had been used in Britain and allows broader lessons to be learnt about the consequences of the reform.

Elections are found to be broadly well run but problems are reported with names missing from the electoral register, polling station accessibility requirements and ballot secrecy problems. Attempted impersonation was exceptionally rare, however, and provided no evidence to support the introduction of voter identification requirements. In fact, these voter identification requirements led to some voters not casting their ballot when they arrived at the polling place, either for reasons of convenience and availability of suitable forms of ID, or reasons of principle and protest. This article therefore contributes to the international literature about the nature of electoral integrity in established democracies, the literature on inclusive voting practices, and the effects of voter identification requirements - where the number of studies remain limited.

The article proceeds by presenting a five-part typology of problems that are regularly thought to occur in polling stations. It then reviews the literature on the known effects of voter identification requirements. The way in which English local elections are run is then explained with the pilot 
schemes explained in historical context. The research design is set out before the results of the study are introduced.

\section{Existing literature on polling place problems}

Elections are an essential part of the democratic process (Beetham 1994; Dahl 1971; James 2020; Przeworski 2018). They provide citizens with the opportunity to hold governments to account and choose their elected representatives. Polling stations are the physical location where citizens have the opportunity to cast their ballot. As well as providing the functional purpose of providing citizens with their opportunity to have their say, this also provides an important ritual (Orr 2016). For Coleman (2013) the act of voting is a social performance which can generate different emotions, memories and anxieties. The act of voting following the toppling of an autocratic regime, for example, can provide cathartic moments. Media images, beamed worldwide, can show people who had been 'long denied the vote, forming winding queues to assert their entry into the enfranchised world stand as semiotic markers of political progress' (p.2).

Nonetheless, problems with electoral integrity are often found in polling stations, as well as other stages of the electoral process. These are important because the consequences can be far reaching, including undermining the legitimacy of government, affecting voter behaviour and set in motion a series of events that might undermine peace and security (Norris 2014). We argue that there are five overlapping themes of problems that are often thought to occur in polling stations, all of which could potentially undermine the quality of the electoral and democratic process. In recent years, there have been some concern about each of these in the UK.

Firstly, given the huge volume of ballot papers, staff and complex laws involved - there is considerable potential for administrative problems. There is increasing cross-national evidence of variations in standards of electoral management (James 2020; James et al. 2019; Norris, i Coma, and Gromping 2016). These are not necessarily the consequence of deliberate partisan efforts to alter the result of elections. Instead, they might result from human error, under-resourcing or poor performance management systems and/or leadership. These are important because individuals can inadvertently lose their ability to exercise their right to vote as a consequence of such difficulties. The UK made international headlines on the night of the 2010 general election when citizens were locked out of polling stations as they closed at $10 \mathrm{pm}$, and they were inconsistently dealt with by officials. Legal clarity was subsequently provided, but there remains evidence of variation in the quality of delivery 
(Clark 2015, 2017). James argued that the UK compared unfavourably in many respects against Canada, using a comparative framework to evaluate electoral management (James 2020).

Secondly, there might be bureaucratic hurdles to citizens casting their vote, which might ultimately determine whether they decide whether to vote - or are even able to do so. As the introduction to the special issue sets out, voters find themselves within a strategic-relational environment which might make voting more or less likely. The administrative time involved in voting can make voting more or less likely. Early voter registration deadlines, limited polling hours and long distances to polling stations are amongst the factors that have been shown to affect whether or not individuals vote (Gimpel and Schuknecht 2003; Hall 2013; James 2012; Orford et al. 2011; Pallister 2017; Wolfinger and Rosenstone 1980). The introduction of individual electoral registration into Britain caused concern that students and younger citizens might be adversely affected (James 2014a). These concerns eventually proved to be well founded with the completeness of the electoral register affected amongst younger groups (James 2020). Campaigners therefore argued strongly for voter registration reform (Bite the Ballot, James, and ClearView Research 2016) to address this.

Thirdly, there might be accessibility problems with polling stations and polling materials which makes it more difficult for citizens with disabilities to cast their vote. Such an experience might send 'the message that people with disabilities are not expected to participate in the political sphere' (Schur, Ameri, and Adya 2017, 1374). Studies have shown that individuals with disabilities are often reported to be less likely to vote and have experienced problems in polling stations (van Hees, Boeije, and de Putter 2019). Convenience voting mechanisms such as absentee voting have therefore been found to increase turnout among those with disabilities (Miller and Powell 2016). The UK Electoral Commission report on the 2015 general election found that 5 per cent of people with disabilities were dissatisfied with the voting process, by contrast with 2 per cent for those without a disability (Electoral Commission 2015, 47-8). Despite this, research on disabled voters' experience in polling stations has been relatively sparse.

Fourthly, polling stations are often highlighted as the physical spaces where parties, state agents and the public might try to exert voter intimidation (Birch 2011; Frye, Reuter, and Szakonyi 2019). Threats of physical violence are often made well in advance of the day of the election, so that the day of the election can itself be relatively free of intimidation. Nonetheless, historical studies from older democracies (Argersinger 1985) and cross-national analyses (Birch and Muchlinski 2018) reveal the persistence of intimidation and violence in and around polling stations. UK elections were historically long thought to be free from electoral malpractices of this type. An evaluation of the $2016 \mathrm{EU}$ referendum, however, did find some problems with inappropriate campaigning at polling stations, 
such as the placement of posters close to polling stations (Clark and James 2016). Physical intimidation inside polling stations was alleged in a court case regarding elections in a London borough (Mawrey 2015).

Fifth, polling stations have been pointed to as a site where electoral fraud might be conducted. This could involve include ballot-box stuffing in favour of one party or candidate, carousel-voting or impersonation (Birch 2011; Lehoucq 2003; Lehoucq and Molina 2002; Schedler 2002). In response to this, some advocate increased security provisions, such as voter identification requirements, removing convenience voting provisions such as mail-in ballots or asking citizens or the use of election monitors (Fund 2008). Critics, however, argue that actual cases of electoral fraud in the older established democracies are fewer and further between than media coverage often implies (Minnite 2010). In the UK, Wilks-Heeg (2008) argued that provisions for postal voting provided opportunities for electoral fraud. Meanwhile, Sobolewska et al. (2015) argued that the structure of Pakistani and Bangladeshi origin communities provided opportunities for undue influence. These findings are not always found in other studies, however (Clark and James 2016).

\section{Existing literature on voter ID requirements}

Voter ID requirements have often been proposed to improve electoral integrity in polling stations, but have been one of the most contested aspects of electoral administration in the US and at the heart of fiercely political 'voting wars' (Hasen 2012; James 2012) Proponents claimed that they are necessary to reduce voter fraud (Fund 2008), while opponents claim that they amount to voter suppression and can or have had a disproportionate effect on minority voters less likely to have the required form of ID (Hajnal, Lajevardi, and Nielson 2017; Minnite 2010; Piven, Minnite, and Groarke 2009). In a review of the US literature Highton (2017) concluded that 'a small number of studies have employed suitable research designs and generally find modest, if any, turnout effects of voter identification laws.' (p.149) Identifying the effects of voter ID requirements on participation is difficult because of a number of methodological problems (Burden 2018; Erikson and Minnite 2009; Highton 2017). As Highton noted, only a few US states initially introduced strict voter ID laws. These reforms were relatively recent and often in tandem with other simultaneous reforms. There is therefore no strict experimental method as voter ID is introduced in states with specific political contexts (Highton 2017). The relative absence of cross-national data on voting requirements has limited the study of other states. There have been important moves to introduce biometric identification in many countries - but there has been relatively little focussing on the impact on turnout (Gelb and Diofasi 2016). 
One approach is to examine who has the required form of identification. Hood III and Bullock III (2008) estimated which registered voters in Georgia lacked a Department of Motor Vehicles-issued form of ID. In the UK, pressure groups such as the Electoral Reform Society criticised the voter identification scheme on the basis that 9.5 million people did not hold a passport in 2011 and 9 million did not have a driving licence in $2013 / 14$. The reforms, they argued, would have a disproportionate effect on those without the necessary forms of ID (Electoral Reform Society 2019). This provides a useful 'worst-case scenario' but makes crude assumptions about whether those with the required form of ID will vote, and makes no allowances for the systems that electoral officials introduce for those without ID. For example, provisional ballots could be granted. Alternatively, other forms of ID could be made available on request - but it would be unclear whether/how many people would apply.

A second approach is to use surveys of citizens' experiences, but citizens may not always report their experiences accurately. One advance has been to use surveys where responses are checked against voter registration files. Hajnal, Lajevardi, and Nielson (2017) therefore used the Cooperative Congressional Election Study and concluded that strict identification laws did have a differentially negative impact on turnout. Grimmer et al. (2018), however, argued that there were data inaccuracies as there are problems in matching the data records. Atkeson et al. (2010) undertook a survey of citizens in New Mexico to identify whether Hispanic and other minority voters were more likely to have been asked for ID than others. Surveys of citizens have been used in Northern Ireland where photographic requirements were introduced in 2002. An Electoral Commission survey suggested that one percent of voters experienced problems with voter ID in the 2007 Northern Ireland Assembly election (Electoral Commission 2014, 25). This would be approximately 11,000 citizens. $^{1}$

A third approach has been to use surveys of poll workers. Atkeson et al. (2010), for example, surveyed poll workers in their New Mexico to ask how frequently they asked for voter ID and why they did so. They concluded that neither the partisan or demo-graphic characteristics of the poll worker affected whether they asked for voter ID (Atkeson et al. 2010, 71). Their survey didn't, however, identify the number of people who were unable to vote because they didn't have the required form of voter identification. Poll worker surveys have not been used to identify the effects of voter ID outside of the US.

In summary, there has been some evidence of the impact voter identification requirements on turnout, especially minority populations but there remain few studies outside of the US. A variety of available methods have been established, but poll worker studies have not been used to explore the effects of voter identification in different polities. 


\section{Inclusive electoral practices in the UK?}

This article empirically focuses on electoral integrity in English polling stations. Elections in England are run by Returning Officers who are appointed by local government units. Returning Officers are responsible for the conduct of the poll and have some discretion over the timing of the count. An Electoral Registration Officer is responsible for compiling the electoral register. Both Returning Officers and Electoral Registration Officers are local government employees but are independent of both central and local government with respect to their electoral duties. They are instead accountable to the courts system as an independent statutory officer and can be prosecuted for being in breach of their duties. Electoral Registration Officers and Returning Officers implement elections according to electoral law which is determined by Parliament in Westminster and appropriate additional secondary legislation set out by the Minister of State. Since 2000, a UK Electoral Commission has provided advice and guidance for election administration, served as the chief counting officer for referendums and has had a statutory duty to evaluate any electoral pilots undertaken by the government. In normal electoral circumstances, with the exception of referendums, the Electoral Commission has no power of direction over electoral administrators on the ground. Electoral justice is primarily dealt with by the court system. Election Courts can be convened by the High Court if a petition is raised challenging the result of an election. There are some important variations across the UK, with different arrangements in Northern Ireland and Scotland, but the focus of this study is solely on local elections in England for reasons that the methods section will explain.

The franchise for local elections is different to general elections, with EU citizens also eligible to vote. Polling stations are open for local elections between $7.00 \mathrm{am}$ and $10.00 \mathrm{pm}$ on the day of the poll, with the count usually taking place immediately afterwards. Electors need to have applied to be registered no later than 12 days before the poll. These applications are processed by local government units who maintain 381 separate local registers in Britain. Votes can also be cast by post if an application is made no later than 11 days before the poll. Proxy votes can be applied for on the basis of disability or absence on the day of the poll 11 days before the poll. Citizens can, however, also apply to cast an emergency proxy vote as late as $5 \mathrm{pm}$ on election day (Electoral Commission 2019). These procedures were the result of efforts by the New Labour governments to make it easier for citizens to cast their ballot (James 2011).

A different policy agenda emerged from the mid-2000s following some high-profile cases of electoral fraud. Six councillors were found guilty of postal vote fraud in Birmingham in 2004, although one successfully appealed. The case caught the headlines after the judge presiding over the election court declared that the levels of fraud would shame a 'banana republic' (Stewart 2006). The same judge 
also oversaw a case where a candidate for mayor of the London Borough of Tower Hamlets was found guilty of a variety of electoral offences (Mawrey 2015). The Labour governments introduced some measures to tackle vulnerabilities for fraud such as tighter provision for postal votes and initiated the move towards individual electoral registration. This momentum was sped up under the Conservative led governments from 2010. Individual electoral registration was legislated for in 2013 and the government asked former Conservative Party chair and Secretary of State for Communities \& Local Government, Eric Pickles, to author a report recommending measures to reduce electoral fraud. One of his recommendations was voter identification (Pickles 2016).

A first step was the introduction of pilot voter ID schemes in the 2018 and 2019 local elections in England. Pilots were run in five authorities in $2018^{2}$ ten in $2019^{3}$ with different models being used in different councils (Cabinet Office 2019, 5-6; Electoral Commission 2018) as set out in Table 1. These pilots were voluntary, with participating councils effectively self-selecting in applying to participate (Cabinet Office 2018a). The vast majority of councils chose not to do so. Two councils - Watford and Woking - participated in both rounds of pilots. Critics of the 2018 pilots noted that most of the participating councils were located in the South of England, traditionally a Conservative-voting region. Indeed, four of the five pilot authorities had Conservative majorities in the 2018 local elections (Dempsey 2018). ${ }^{4}$ In 2019 this regional distribution changed with four in the Midlands - Broxtowe, Derby, North Kesteven and North West Leicestershire - and two in the north - Craven and Pendle and the remaining four in the South. The Conservative Party were the largest in all but one of the councils after the 2019 elections, being the majority in three, and the largest party in a no overall control situation in a further six (Uberoi 2019). With the exception of the London Borough of Bromley, and Swindon and Derby which are unitary councils, the remainder were all district councils. Notable by their absence were both Labour controlled councils, and large metropolitan councils where many groups argued to be potentially disadvantaged by voter ID were most likely to be resident.

The aim of the voter identification pilots was therefore to reduce opportunities for electoral fraud notably personation. Critical voices, however, argued that the piloting of ID was unlawful (Green 2019) and in breach of human rights commitments (Stanford 2018).

[Insert Table 1 about here]

\section{Research Methods}

This article aims to address the following questions:

1. What problems are reported in polling stations at English local elections? 
2. To what extent did the introduction of voter identification requirements help or hinder these problems?

Poll worker studies have become an established method for identifying the frequency and nature of problems with electoral integrity in polling stations (Clark and James 2017). The officials who were present in polling stations on the day can be conceived as 'street level bureaucrats' (Lipsky 1980) who have intimate frontline knowledge of the mundane everyday practice of elections (Durose 2009). They therefore have a different vantage point from which we can see the electoral process than voter surveys. They are also actors who are much closer 'to the ground' than experts, whose opinions are often used to assess the frequency of other forms of electoral integrity (James 2020, 33-58; Martínez i Coma and van Ham 2015). Poll worker surveys may, however, underestimate the effects of voter ID on participation. Electors may decide not to travel to the polls because of the ID requirements and their actions would not feature in the experience of poll workers. Poll worker studies therefore provide a conservative estimate of the effects.

Poll worker surveys were conducted in the 2018 and 2019 English local elections based on a questionnaire design used in the 2015 general election (Clark and James 2017). The Electoral Commission has a statutory duty to undertake evaluations of electoral pilots and therefore they conducted a poll worker survey, partially based on the research design proposed by the authors, in the pilot areas. The authors approached all returning officers in remaining non-participating local authorities via email, asking them to circulate the survey to their poll workers. The surveys contained many identical questions about the frequency of problems in polling stations.

The surveys provided a greater number of responses than any previous poll worker survey undertaken in the UK. The authors' surveys generated 2,276 responses in 2018 and a further 460 in 2019. The surveys therefore provided extensive information about the frequencies of problems at polling stations. These also included qualitative responses that could be used to expand on the nature of the problems experienced at polling stations. Qualitative comments were read by the authors and then selected to illustrate examples. A formal coding system was not therefore used. The 2019 surveys saw a lower response rate because European Parliament elections followed shortly after the local elections. This meant that fewer local authorities circulated the survey due to the increased pressure. In addition, the Electoral Commission surveys generated 1,436 in 2018 and 1,803 in 2019. This provides a total of 5,973 responses. The sample was broadly representative of the population in terms of the coverage of local authorities included. ${ }^{5}$

Data collected from non-pilot areas can be compared against the pilot areas to examine what effect, if any, the different voter ID requirements had on the running of the elections. The pilots brought 
considerable investment in publicity about the form of voter identification that was required in each pilot area, which might not be replicated at other events. Written evidence to the House of Commons Public Administration and Constitutional Affairs Committee suggested that around $£ 353,000$ had been spent on awareness raising in the five pilot authorities in 2018, while additional administrative costs amounted to $f 1,385,934 .{ }^{6}$ Voter ID also featured prominently in the national media as critics such as the Electoral Reform Society and Labour Party argued that it would disenfranchise voters (Walker 2019). This may have increased awareness of the voting procedures and boosted turnout to be higher than it might otherwise have been. The effects of voter identification in a pilot situation might also be very different to a permanent reform, where voters would become used to the requirements over several elections and might therefore be more likely to bring the required identification. Nonetheless, the pilots provide an important opportunity to establish the likely effects of permanent reforms.

\section{Results: Polling Station Problems in English Local Elections}

The article now reports on the quantitative and qualitative evidence found from the surveys with respect to the five different themes of potential problems.

\section{Administrative problems}

Table 2 summarises responses about whether some possible administrative problems occurred. The general picture was very similar to earlier studies on the 2015 general election in that few problems were reported (Clark and James 2017). The polling process was described as going smoothly with few problems setting up or closing polling stations. In some cases, this was because problems were identified in advance and solutions found. In one case there were major problems with incorrectly printed electoral registers, but this was identified the day before the register was collected, for example.

This is not to say that the day was without incident. One polling station, for example, had to be evacuated as the fire alarm had developed a faulty sensor. A temporary polling station therefore had to be set up in the back of a car until the alarm was silenced and the building was confirmed as safe to enter.

Access to the buildings was sometimes problematic. One poll worker noted that:

School gates were closed and no one was there to open them so voters, disabled or not, were having to walk a long distance to get to us. Some even said they were going to turn around and go home rather than coming in. Some voters could have done this without our knowledge. 
In other cases, facilities were poor which meant that working conditions for poll workers were cramped. Buildings would sometimes also be used for several purposes on the day which might have undermined the quality of service. In one instance 'a wake was being held in the same building and it got a bit heated.'

[Insert Table 2 about here]

Poll workers generally described themselves as working well together. 'My team worked very well together and it was a fantastic day/experience,' said one. The 'feeling of camaraderie' was praised one poll worker pointed out that their presiding officer 'was friendly and taught me a lot of extras'. But relations were not always harmonious. This potentially led to the quality of service to the voter being undermined:

'One of the workers is quite rude and insensitive and regularly upsets voters.... Although I've mentioned it nobody seems concerned. I often have to diffuse situations and have decided I am going to ask to work at another station next time as I find it embarrassing and hard work.'

One issue that has been thought to have made running elections more difficult has been the complexity of electoral law. Earlier research found that this was a problem which could lead to errors in the electoral process and drain resources (James 2014b) and the Law Commission subsequently published recommendations to consolidate electoral law (Law Commissions 2016). The non-pilot surveys asked about whether the law was too complex to understand quickly and easily. Although no problems were directly linked to this, there was a significant proportion of 15.9 per cent of responding poll workers who found electoral law difficult to understand and follow quickly, while a further 31.5 per cent were neutral, neither agreeing nor disagreeing.

\section{Bureaucratic hurdles}

One form of bureaucratic hurdle that voters might experience is a queue or long wait time (King, this issue). Table 2 illustrates that these were relatively rare. Polling stations may have been put under less pressure than they would be at a general election because of lower turnout (although more staff might have been employed at a general election). Where they did occur, logistical problems were often the cause. One poll worker explained that: 
There were also some isolated case of citizens 'who turned up after the polls were closed, around 10:05, and insisted to vote', but were presumably refused since the law only permits those already in a queue to vote to cast their ballot after the $10 \mathrm{pm}$ close of poll. A positive correlation was found between queues and population density. Queues were more likely in higher density urban areas. ${ }^{7}$

\section{[Insert Table 3 here]}

Poll workers were asked whether they experienced people asking to vote who were not on the register (see Table 3). In a legal sense, poll workers correctly turn prospective voters away in these circumstances. However, this is a bureaucratic hurdle for citizens because in some polities they could vote without prior voter registration at any polling station (James, 2019). This was one of the more frequent problems with roughly half of polling stations reporting a problem with at least one voter. Pearson's correlations also showed that it was more likely to be reported in urban areas $(\beta=.226, p<$ 0.01). ${ }^{8}$ Electoral Commission data for 2018 suggest that around 1400 voters were affected in those local elections. ${ }^{9}$ Poll workers cited various examples this. For instance:

\footnotetext{
'Someone had moved recently from one area of [location given] to another, he assumed because he pays his council tax on new house his election rights automatically moved over at the same time, which stopped him from voting'.

'Disruptive voter unhappy at not being on electoral roll.'

'Good turn out from younger people but I was surprised at how many didn't realise you need to be registered to vote.'
}

Qualitative comments suggested that the problem was also that they had attended the wrong polling station, perhaps because the location had changed. As one poll worker explained:

'People complained they couldn't find the polling station after a small change of location despite a letter telling them it changed, being notified on their poll card and many fluorescent signs outside. We were probably only about 200 yards away.'

Others had no election to vote in:

'We explained that there was no poll where they live and thanked them for making the efforts to try and vote'. ${ }^{10}$

It was noticeable that problems, though significant because they involved voters being turned away from the polls, were less frequently reported than they were at the 2015 general election where a similar survey was run and 69 per cent reported at least one problem (Clark and James 2017), at the 2016 Brexit referendum where there were some angry citizens unable to vote (Clark and James 2016) or at the 2019 European elections a few weeks after the 2019 local elections described here (James 
2019). One explanation for the difference against a general election might be that voters in local elections are more aware of their registration status because they are better informed and more motivated about politics at all levels. ${ }^{11}$ It might also be that the move to individual electoral registration between 2014-5 had created confusion at previous electoral events, and this confusion had subsided over time.

\section{Accessibility}

The surveys asked whether disabled voters experienced any problems with access to the polling stations and completing ballot papers. Table 4 illustrates that some problems with accessibility were experienced, especially for wheelchair users. Problems were more likely to be found in the London Boroughs $(\beta=.135, p<0.01)$. Poll workers gave many examples, including:

'Difficult access due to scaffolding outside building slightly obstructing the entrance especially for buggies and wheelchairs'

'Venue had steep and uneven step which made access difficult'

'We did not have any disabled voters in the polling station but this could have been because there was no availability of disabled parking directly outside the entrance to the station.'

'exiting the station... they were not able to turn their mobility scooter until we moved tables to make a larger space.'

In some cases, this seemed to mean that the usual processes that ensured ballot security such as the provision of private booths appeared to be compromised:

'No wheelchair access, as the presiding officer I took ballot papers to people in wheelchairs to complete.'

'Disabled person... had a sight problem and I assisted in marking their paper and completing associated form.

Some problems were responded to the problem with aids provided for the purpose:

Two people struggled to read the papers, but this was quickly handled with the provided magnifying glass and aids

In each of these cases however, the poll worker was simply complying with the recommendations and procedures contained in their training, although these procedures have been criticized by sight-loss charities. $^{12}$ 
Language also posed a problem in some areas:

'Dealing with voters where their first language is not English. A list of general questions and answers in a selection of languages relevant to the area. In my locality Slovak, Lithuanian, Russian, Polish etc'

This meant that poll workers were unable to communicate the process to voter in some instances, but also raises questions about those voters' awareness of the parties and candidates.

\section{Voter intimidation and ballot secrecy}

Table 5 suggests that problems with voter intimidation are rare with the vast majority reporting no problems. Isolated cases were described in the qualitative comments, including one case in a London borough where: 'A person seemed to exercise undue influence on another voter.' Other cases were gender (rather than ethnicity) based:

'[M]en try to tell their partners how to vote.'

'Men telling women who were standing in polling booths how to vote, and in loud voices.'

'Some ladies handing their ballot paper to a man so we had to intervene. They then tried to go in the booth together, again intervened. I am not sure some of the ladies knew who to vote for and were relying on'

Some forms of intimidation came through the party agents, whose behaviour was sometimes described as inappropriate. Examples cited in the qualitative comments were mostly about the behaviour of tellers, or party workers, who were sometimes reported as off-putting to voters:

'Voters felt they were obliged to give information to the tellers outside the station due to the words used by the tellers'

Even if they were not necessarily doing anything legally wrong, some citizens were concerned about their presence:

'One voter vociferously complained about the teller's presence. The tellers were acting reasonably simply asking for the numbers'

Tellers were also sometimes inexperienced, 'didn't know what they were meant to do and expected polling station staff to advise them.' Other forms of inappropriate activity cited by poll workers 
included the candidate entering the polling station and the display of party flags in cars parked close to polling stations.

Poll workers were also asked whether they experienced problems with ballot secrecy. The vast majority 'agreed' or 'strongly agreed' that there were no problems maintaining the secrecy of the ballot in polling stations - but 7.0 per cent 'disagreed' or 'strongly disagreed.' Ballot secrecy was undermined for a number of reasons. One reason was related to disability and accessibility. Another was poor equipment and location:

'The polling booths have no curtains across them so it is difficult to stop family members looking at each other's ballot papers and consulting on who to vote for or checking who the other(s) have voted for.'

Conversely, some electors questioned whether their ballot secrecy would be guaranteed:

'when they realised their elector number was being written on the "Corresponding Number List".

[Insert Table 5 here]

\section{Impersonation and fraud}

Respondents were asked whether they were suspicious that any electoral fraud had taken place and whether they had confidence in the stated identity of the elector that they were presenting ballot papers to. Combining the data from the pilot and non-pilot areas, Table 6 shows that electoral fraud in polling stations was thought to be very rare. Suspicions about the identity of the elector were also very rare.

\section{[Insert Table 6 here]}

Qualitative comments revealed that the problems posed by the public in polling stations were much more varied. These included taking photos: 
Questions were asked by the public about why pencils and not pens were provided. This was a problem reported in 2016, where some campaigners claimed that electoral officials would rub-off votes marked in pencil (Clark and James 2016). One respondent claimed that:

'at least 3 people challenged why we used pencils and we offered them pens and tried to explain it was just because pencils don't run out and that we could not access their ballot paper after they put it in the box anyway'

Voters could also be challenging in other ways, such as being intoxicated:

'A drunk male arrived around lunch time, he did have his poll card and was entitled to vote at my polling station, quickly realising that he was drunk he was ushered through the process, this was because he was shouting out that there were only three parties and no Green Party. He was given time to vote and left without incident.'

Or in another experience:

A man with mental health issues who wouldn't stop talking after he voted. He wanted to know our blood group; star sign; domestic arrangements; etc. But at least he came to vote.

In short, impersonation was not a problem and poll workers experienced a greater variety of other challenges.

An earlier claim has been that Pakistani- and Bangladeshi-origin communities in England share a wide range of vulnerabilities, which may make them susceptible to becoming victims of electoral fraud (Sobolewska et al. 2015). This research has been used to claim that electoral fraud is therefore more likely to occur within these communities 'clan-based voting that has entered this country from Pakistan and Bangladesh' (Golds 2015). Table 7 provides bivariate correlations in the first column of the relationship between different problems in polling stations and the percentage of the combined Pakistani and Bangladeshi community (measured by ethnicity from Table KS201UK of the 2011 census). Partial correlations are shown in the second column controlling for population density. Correlations are low in all cases and usually not significant after population density has been controlled for. There is therefore little statistical or qualitative evidence based on these surveys to suggest that problems with fraud is higher in these communities than any others.

[Insert Table 7 about here]

\section{The Impact of Voter Identification Requirements}


Did the piloting of voter identification have any effect on the running of the poll? There was virtually no difference between the pilot and non-pilot areas in terms of whether electoral fraud was suspected. We might imply from this that the scheme had no effect - but a difference was probably never likely given that suspected fraud was so infrequent in the first place. Interestingly, a higher proportion of respondents in the pilot areas reported encountering electors whose identity they were unsure of. In the pilot areas 7.2 per cent of poll workers encountered electors whose identity they were suspicious about. In the non-pilot areas, the figure was 4.7 per cent. An ANOVA crosstab table Chi-square tests were run to see whether this different was statistically significant. It was significant at the $p<.001$ level. Voter ID requirements therefore seemed to make poll workers slightly less confident. When ID was requested, more stringent forms such as photographic ID generated more confidence (Table 8).

[Insert Table 8 here]

In the pilot areas poll workers were also directly asked about the impact of the pilots as part of the survey organised by the Electoral Commission. Approximately two-thirds of poll workers (65.3 per cent) agreed that the ID requirements made voting more secure. But a third (31.3 per cent) neither agreed or disagreed and this was the modal response for the photo ID pilots.

Was this a new bureaucratic hurdle which led to some citizens not voting? This was a heavily contested question in the aftermath of the pilots. In 2018, estimates established by different methods ranged from 340 to 4,000 , a figure later suggested to have been considerably overestimated (Dempsey, 2018). In 2019, between 7-800 were estimated to not have returned to vote in the ten pilot councils after having been turned away for not having ID (Dempsey 2018; Uberoi 2019). Table 9 illustrates that over half of poll workers reported turning away at least one voter for not having the required form of identification in the Electoral Commission data. A small proportion of 1.3 per cent of poll workers turned more than 10 voters away. This was a more frequently experienced problem than citizens being turned away because of incomplete electoral registers discussed above and does therefore represent a considerable bureaucratic hurdle. Meanwhile, a quarter of poll workers experienced a voter who was able to provide voter identification but refused to comply. This suggests that voter ID might be a burden for logistical convenience reasons - but also a barrier on philosophical and ethical reasons for voters. While some are able to provide ID, they might decide not to present it in protest.

[Insert Tables 9 and 10 about here] 
Comments from the non-pilot areas provided mixed views about whether they wished to have voter ID implemented more broadly. Some were openly resistant and thought that some groups would be adversely affected:

\begin{abstract}
'Although I enjoy working as a poll worker I would be much less willing to work if compulsory identity checks were introduced.'

'Some identification would be a good idea, but disenfranchisement of vulnerable people will be inevitable if the currently experiment is extended: there are many people in the community without photo id (e.g. driving licence or passport). Furtherance of identification at the poll can only take place if a national identity card is issued if we are to see a true democratic process still.'

'In my experience the new voter id rules seek to solve a problem which simply doesn't exist....in my experience voting at the polling station is remarkable for the trust paid to the electorate and that they repay it by vanishingly low levels of fraud. The delight of many voters in being able to vote without id or a polling card is palpable and I cannot see the need to put up any further barriers.
\end{abstract}

In contrast, some others argued that:

I think that an identification process should be introduced as part of the voting. Some form of ID should be required to prove that the voter is who they say they are as I feel that this part of the process is open to fraud. Lots of voters who come into the Polling Station do question this with us and there is no answer that we can give them. I just feel that asking for a name and their address is not sufficient and photo ID of some sort is needed.

\title{
Conclusions
}

Polling stations play a pivotal role in the democratic process, but are often the site where claims of electoral malpractices are made, in both older and transitional democracies. This article has made an important contribution in rectifying some of these claims by providing the most extensive available data on the frequency and nature of problems at contemporary English polling stations. It has done so through a rich description using a mix of qualitative and quantitative data. The experiences of poll workers on the ground, conceptualised as street-level bureaucrats, provide a deep insight how elections function in practice.

Elections were found to be broadly well run, with fewer problems than are experienced at general elections. There are, however, persistent problems with people failing to register and therefore being eligible to vote in any given election, polling station accessibility requirements and inappropriate behaviour from party agents/candidates. Attempted impersonation was exceptionally rare. This 
reinforces findings from earlier studies (Clark and James 2016, 2017), but with a much larger dataset than was previously used. The data provides no evidence to suggest that electoral fraud is more prevalent in Pakistani and Bangladeshi communities counter to existing research and public debate (Sobolewska et al. 2015).

The article provides additional evidence that identification requirements can lead some voters not to vote, as the evidence was that some voters were unable to present the necessary form of ID on the day. The frequency of this problem was more common than those turned away for registration reasons. Moreover, some voters did not vote present voter ID out of ideological reasons. This presents an important new link between voter identification requirements and turnout which has not been discussed in the literature to date. Importantly, the introduction of voter identification in polling stations reduced the confidence of poll workers that the citizens asking to vote were who they said they were.

There are therefore important lessons for academic research, but also policy. Recent UK government focus on targeting electoral fraud, often with a focus on Pakistani and Bangladeshi communities, seems to be misjudged, and out of line with the most prevalent problems in polling stations. Voter ID does not seem to be a necessary reform and may affect other aspects of the electoral process. Reforms are instead needed to improve the completeness of the electoral register and improve accessibility for disabled citizens to make elections more inclusive. 
Bibliography

Argersinger, Peter H. 1985. "New Perspectives on Election Fraud in the Gilded Age." Political Science Quarterly, 100, (4), p. 669-87.

Atkeson, Lonna Rae, Lisa Ann Bryant, Thad E. Hall, Kyle Saunders, and Michael Alvarez. 2010. "A new barrier to participation: Heterogeneous application of voter identification policies." Electoral Studies, 29, (1), p. 66-73.

Beetham, David. 1994. "Key Principles and Indicies for a Democratic Audit." In Defining Democracy, edited by David Beetham. London: Sage.

Birch, Sarah. 2011. Electoral Malpractice. Oxford: Oxford University Press.

Birch, Sarah, and David Muchlinski. 2018. "Electoral Violence: patterns and trends." In Electoral Integrity and Political Regimes: Actors, Strategies and Consequences, edited by Holly Ann Garnett and Margarita Zavadskaya, 100-12. Abingdon and New York: Routledge.

Bite the Ballot, Toby S. James, and ClearView Research. 2016. Getting the Missing Millions Back on the Electoral Register: A vision for voter registration reform in the UK. London: All Parliamentary Party Group on Democratic Participation.

Burden, Barry C. 2018. "Disagreement over ID Requirements and Minority Voter Turnout." The Journal of Politics, 80, (3), p. 1060-3.

Cabinet Office, 2019. 2019. Voter ID Pilots 2019: Pre-Pilot Equality Considerations. London: Cabinet Office.

Cabinet Office. 2018a. Electoral Integrity Pilots Prospectus 2018. London: Cabinet Office.

- - - 2018b. Public Adminstration and Constitutional Affairs Committee Voter ID and Electoral Intimidation. London: Cabinet Office.

Clark, Alistair. 2015. "Public Administration and the Integrity of the Electoral Process in British Elections." Public Administration, 93, (1), p. 86-102.

- - . 2017. "Identifying the determinants of electoral integrity and administration in advanced democracies: the case of Britain." European Political Science Review, 9, (03), p. 471-92.

Clark, Alistair, and Toby S. James. 2016. An Evaluation of Electoral Administration at the EU Referendum. London: Electoral Commission.

-- - 2017. "Poll Workers." In Election Watchdogs, edited by Pippa Norris and Alessandro Nai. New York: Oxford University Press.

Clark, Alistair, and Timothy Krebs. 2012. "Elections and Policy Responsiveness." In Oxford Handbook of Urban Politics, edited by Karen Mossenberger, Susan E. Clarke and Peter John. Oxford: Oxford University Press.

Coleman, Stephen. 2013. How voters feel: Cambridge University Press.

Dahl, R. 1971. Polyarchy: Participation and Opposition. New Haven: Yale University Press.

Dempsey, Noel. 2018. Local Elections 2018. London: House of Commons Library.

Durose, Catherine. 2009. "Front-line workers and local knowledge: Neighbourhood stories in contemporary UK local governance." Public Administration, 87, (1), p. 35-49.

Electoral Commission. 2014. Electoral fraud in the UK: Final report and recommendations. London: Electoral Commission.

-- - 2015. The May 2015 UK elections: Report on the administration of the 7 May 2015 elections. London: Electoral Commission.

- - - 2018. May 2018 voter identification pilot schemes. Electoral Commission.

- - . 2019. "Timetable for local elections in England: 2 May 2019." p.

Electoral Reform Society. 2019. Voter ID: Undermining your Right to Vote. https://www.electoralreform.org.uk/campaigns/upgrading-our-democracy/voter-id/.

Erikson, Robert S, and Lorraine C Minnite. 2009. "Modeling problems in the voter identificationvoter turnout debate." Election Law Journal, 8, (2), p. 85-101. 
Frye, Timothy, Ora John Reuter, and David Szakonyi. 2019. "Hitting them with carrots: Voter intimidation and vote buying in Russia." British Journal of Political Science, 49, (3), p. 857-81.

Fund, John. 2008. Stealing Elections: How voter fraud threatens our democracy. Encounter Books: New York and London.

Gelb, Alan, and Anna Diofasi. 2016. "Biometric Elections in Poor Countries: Wasteful or a Worthwhile Investment?". p.

Gimpel, J. G., and J. E. Schuknecht. 2003. "Political participation and the accessibility of the ballot box." Political Geography, 22, (5), p. 471-88.

Golds, Peter. 2015. 'An urgently needed plan of action to stop electoral fraud'. Conservative Home. https://www.conservativehome.com/platform/2015/05/peter-golds-an-urgently-neededplan-of-action-to-stop-electoral-fraud.html.

Green, Heather Dawn. 2019. "The voter ID pilots: an unlawful electoral experiment." Public Law, 2019, p. 242-50.

Grimmer, Justin, Eitan Hersh, Marc Meredith, Jonathan Mummolo, and Clayton Nall. 2018. "Obstacles to Estimating Voter ID Laws' Effect on Turnout." The Journal of Politics, 80, (3), p. 1045-51.

Hajnal, Zoltan, Nazita Lajevardi, and Lindsay Nielson. 2017. "Voter identification laws and the suppression of minority votes." The Journal of Politics, 79, (2), p. 363-79.

Hall, Thad E. 2013. "US Voter Registration Reform." Electoral Studies, 32, (4), p. 589-96.

Hasen, Richard L. 2012. The voting wars: From Florida 2000 to the next election meltdown. Grand Rapids, MI: Yale University Press.

Highton, Benjamin. 2017. "Voter Identification Laws and Turnout in the United States." Annual Review of Political Science, 20, (1), p. 149-67.

Hood III, MV, and Charles S Bullock III. 2008. "Worth a thousand words? an analysis of Georgia's voter identification statute." American Politics Research, 36, (4), p. 555-79.

James, T. S. 2014a. "The Spill-Over and Displacement Effects of Implementing Election Administration Reforms: Introducing Individual Electoral Registration in Britain." Parliamentary Affairs, p. 281.

James, Toby S. 2011. "Fewer 'costs,' more votes? UK Innovations in Electoral Administration 20002007 and their effect on voter turnout." Election Law Journal, 10, (1), p. 37-52.

-- . 2012. Elite Statecraft and Election Administration: Bending the Rules of the Game. Basingstoke: Palgrave Macmillan.

-- - 2014b. "Electoral Management in Britain." In Advancing Electoral Integrity, edited by Pippa Norris, Richard Frank and Ferran Matinez I Coma, 135-64. New York: Oxford University Press.

- - . 2019. "\#DeniedMyVote - why many EU citizens were unable to vote in the European Parliament elections." Democratic Audit, 30th May 2019.

http://www.democraticaudit.com/2019/05/30/deniedmyvote-why-many-eu-citizens-wereunable-to-vote-in-the-european-parliament-elections/.

- - . 2020. Comparative Electoral Management: Performance, Networks and Instruments. London and New York: Routledge.

James, Toby S., Holly Ann Garnett, Leontine Loeber, and Carolien van Ham. 2019. "Electoral Management and Organizational Determinants of Electoral Integrity." International Political Science Review, 40, (3), p. 295-312.

Law Commissions. 2016. Electoral Law: An Interim Report. London: Law Commissions.

Lehoucq, F.E. 2003. "Electoral Fraud: Causes, Types and Consequences." Annual Review of Political Science, 6, p. 233-56.

Lehoucq, F.E., and I. Molina. 2002. Stuffing the ballot box. Cambridge and New York: Cambridge University Press.

Lipsky, Michael. 1980. Street Level Bureaucracy. New York: Russell Sage Foundation. 
Martínez i Coma, Ferran, and Carolien van Ham. 2015. "Can experts judge elections? Testing the validity of expert judgments for measuring election integrity." European Journal of Political Research, 54, (2), p. 305-25.

Mawrey, Richard. 2015. "Andrew Erlam v. Mohammed Luther Rahman." In M/350/14, edited by High Court of Justice.

Miller, Peter, and Sierra Powell. 2016. "Overcoming Voting Obstacles:The Use of Convenience Voting by Voters With Disabilities." American Politics Research, 44, (1), p. 28-55.

Minnite, Lorraine C. 2010. The Myth of Voter Fraud. Cornell University Press: Ithaca, New York. Norris, Pippa. 2014. Why Electoral Integrity Matters. New York: Cambridge University Press.

Norris, Pippa, Ferran Martinez i Coma, and Max Gromping. 2016. The Year in Elections, 2015. Sydney and Harvard Universities: Electoral Integrity Project.

Northern Ireland Assembly. 2007. Research Paper 01/07: Northern Ireland Assembly 2007.

Orford, S., C. Rallings, M. Thrasher, and G. Borisyuk. 2011. "Changes in the probability of voter turnout when resiting polling stations: a case study in Brent, UK." Environment and Planning C: Government and Policy, 29, (1), p. 149-69.

Orr, Graeme. 2016. Ritual and rhythm in electoral systems: A comparative legal account. Abingdon and New York: Routledge.

Pallister, Kevin. 2017. Election Administration and the Politics of Voter Access: Routledge.

Pickles, Eric. 2016. Securing the ballot: Report of Sir Eric Pickles' review into electoral fraud. London.

Piven, Frances Fox, L. Minnite, and M. Groarke. 2009. Keeping Down the Black Vote. London and New York: The New Press.

Przeworski, Adam. 2018. Why bother with elections? : John Wiley \& Sons.

Schedler, Andreas. 2002. "The menu of manipulation." Journal of Democracy, 13, (2), p. 36-50.

Schur, Lisa, Mason Ameri, and Meera Adya. 2017. "Disability, voter turnout, and polling place accessibility." Social Science Quarterly, 98, (5), p. 1374-90.

Sobolewska, Maria, Stuart Wilks-Heeg, Eleanor Hill, and Magna Borkowska. 2015. Understanding electoral fraud vulnerability in Pakistani and Bangladeshi origin communities in England. A view of local political activists. Manchester and Liverpool: Centre on Dynamics of Ethnicity.

Stanford, Ben. 2018. "Compulsory Voter Identification, Disenfranchisement and Human Rights: Electoral Reform in Great Britain." European Human Rights Law Review, 23, (1), p.

Stewart, John. 2006. "A Banana Republic? The Investigation into Electoral Fraud by the Birmingham Election Court." Parliamentary Affairs, 59, (4), p. 654-67.

Uberoi, Elise. 2019. Local Elections 2019. London: House of Commons Library.

van Hees, Suzanne G. M., Hennie R. Boeije, and Iris de Putter. 2019. "Voting barriers and solutions: the experiences of people with disabilities during the Dutch national election in 2017." Disability \& Society, 34, (5), p. 819-36.

Walker, Peter. 2019. "Voter ID trial at local elections is a waste of time, say campaigners." Guardian, 30 April 2019. https://www.theguardian.com/politics/2019/apr/30/voter-id-trial-localelections.

Wilks-Heeg, Stuart. 2008. Purity of Elections in the UK: Causes for Concern. York: Joseph Rowntree Trust.

Wolfinger, Raymond E., and Steven J. Rosenstone. 1980. Who Votes? New Haven, CT: Yale University Press.

\footnotetext{
${ }^{1}$ The electorate was 1,107,904 (Northern Ireland Assembly 2007, 5). One percent of this figure is $11,090$.

${ }^{2}$ Bromley, Gosport, Watford, Swindon and Woking.

${ }^{3}$ Braintree, Broxtowe, Craven, Derby, Mid-Sussex, North Kesteven, North-West Leicestershire, Pendle, Watford, and Woking councils took part.

${ }^{4}$ The exception was Watford with a $72 \%$ seat share for the Liberal Democrats, a share the party maintained in 2019.
} 
${ }^{5}$ Local elections took place in 150 councils in 2018, and 248 in 2019 (Dempsey 2018; Uberoi 2019). Poll workers from 68 councils took part. Councils represented included 11 (16.2\%) Metropolitan districts, 7 (10.2\%) London boroughs, 7 (10.2\%) Unitary authorities and 43 (63.3\%) districts. This compares to a population of 319 local councils in England (excluding County Councils) of which 36 (11.1\%) were Metropolitan districts, 32 (11.1\%) were London boroughs, 55 (17.2\%) were unitary authorities and 192 (60.1\%) were district councils. The sample was therefore broadly representative of the population.

${ }^{6}$ The evidence suggested that, depending on what model of ID was chosen, a national roll-out could cost anywhere between $f 4.3 \mathrm{~m}$ and $£ 20.4 \mathrm{~m}$ in a UK general election (Cabinet Office 2018b). Interestingly, this written evidence, although published by parliament, was marked Official Sensitive by the Cabinet Office.

${ }^{7}$ Pearson's correlations with population density (measured using data from Table QS102EW of the 2011 Census) were positive associated with 'queues at the polling station' ( $\beta=.114, p<0.01)$ and 'queues at the polling station towards the end of polling day' ( $\beta=.125, p<0.01$ ).

${ }^{8}$ The correlation was against population density measured using data from Table QS102EW of the 2011

Census.

${ }^{9}$ Data available at: https://www.electoralcommission.org.uk/who-we-are-and-what-we-do/elections-andreferendums/past-elections-and-referendums/england-local-council-elections/results-and-turnout-2018-mayengland-local-elections, accessed $16^{\text {th }}$ September 2019.

${ }^{10}$ Not all English local authorities are on the same election timetable. Some elect by thirds, and therefore have effectively annual elections. Others are all-out elections, held every four years. In any given round of English local elections, there are a sizeable number of councils not holding local elections in that particular year. Elections were held in 150 councils in 2018.

${ }^{11}$ There is a suggestion from American research on local voting behaviour that lower turnouts in local contests mean that only the better informed and more motivated voters' turnout to vote in the first place. See Clark and Krebs (2012) for discussion.

${ }^{12}$ See the Royal National Institute for the Blind's 'Turned Out' series of reports

https://www.rnib.org.uk/campaigning-policy-and-reports-hub-access-information/access-information-reports [16/9/2019]. 


\begin{tabular}{|l|l|l|}
\hline Model type & Description & Usage \\
\hline Poll card model & $\begin{array}{l}\text { Electors were required to present their poll card, } \\
\text { an item which is posted to all electors, before } \\
\text { being issued a ballot paper. Replacement poll } \\
\text { cards were available on demand. Should they } \\
\text { not be able to produce a poll card then } \\
\text { alternatives included photographic identification } \\
\text { such as a passport. }\end{array}$ & $\begin{array}{l}\text { 2018: Swindon, Watford } \\
\text { 2019: Mid-Sussex, Watford, } \\
\text { North West Leicestershire }\end{array}$ \\
\hline Photo ID model & $\begin{array}{l}\text { Electors were required to show a form of } \\
\text { photographic identification. If they could not } \\
\text { produce one then they were required to apply } \\
\text { for an electoral identify document, up until 5pm, } \\
\text { the day prior to the poll }\end{array}$ & $\begin{array}{l}\text { 2018: Bromley, Gosport, Woking } \\
\text { 2019: Pendle and Woking }\end{array}$ \\
\hline Mixed model & $\begin{array}{l}\text { Electors could provide one form of listed } \\
\text { photographic ID or two forms non-photographic } \\
\text { ID such as a bank card, council tax demand, } \\
\text { mortgage statement or birth certificate. }\end{array}$ & $\begin{array}{l}\text { 2019: Braintree, North Kesteven, } \\
\text { Craven, Broxtowe and Derby. }\end{array}$ \\
\hline
\end{tabular}

Table 1: Voter-ID pilots. Source: authors based on (Cabinet Office 2019, 5-6; Electoral Commission 2018)

\begin{tabular}{|l|l|l|l|l|l|l|}
\hline & $\begin{array}{l}\text { Strongly } \\
\text { Disagree }\end{array}$ & Disagree & $\begin{array}{l}\text { Neither } \\
\text { agree or } \\
\text { disagree }\end{array}$ & Agree & $\begin{array}{l}\text { Strongly } \\
\text { agree }\end{array}$ & N \\
\hline $\begin{array}{l}\text { Problems setting up polling } \\
\text { station }\end{array}$ & 67.7 & 23.5 & 3.5 & 3.9 & 1.4 & 2609 \\
\hline $\begin{array}{l}\text { Problems closing polling } \\
\text { station }\end{array}$ & 72.6 & 23.3 & 2.4 & .8 & .8 & 2606 \\
\hline $\begin{array}{l}\text { Poll workers worked well } \\
\text { together }\end{array}$ & 1.9 & 1.0 & 2.2 & 20.4 & 74.5 & 2616 \\
\hline $\begin{array}{l}\text { Voting process went } \\
\text { smoothly at my polling } \\
\text { station }\end{array}$ & 2.1 & .5 & 1.5 & 24.3 & 71.6 & 2613 \\
\hline $\begin{array}{l}\text { Problems with queues during } \\
\text { the day }\end{array}$ & 75.0 & 20.5 & 2.4 & .4 & 1.6 & 2602 \\
\hline $\begin{array}{l}\text { Problems with queues } \\
\text { towards end of the day }\end{array}$ & 77.3 & 19.4 & 1.8 & .3 & 1.3 & 2596 \\
\hline
\end{tabular}

Table 2: Administrative problems experienced. Author's data only.

\begin{tabular}{|l|l|l|l|l|l|l|}
\hline & None & 1 & $2-5$ & $6-10$ & $10+$ & $\mathrm{N}$ \\
\hline $\begin{array}{l}\text { People asking to vote, who were not on the } \\
\text { electoral register }\end{array}$ & 52.7 & 23.4 & 20.1 & 1.6 & .5 & 4022 \\
\hline
\end{tabular}

Table 3: Voters turned away from polling stations (\%). Author's and Electoral Commission data combined.

\begin{tabular}{|l|l|l|l|l|l|l|}
\hline & None & 1 & $2-5$ & $6-10$ & $10+$ & $\mathrm{N}$ \\
\hline $\begin{array}{l}\text { Disabled voters having problems with access to } \\
\text { the polling station }\end{array}$ & 91.4 & 5.9 & 2.4 & .3 & .1 & 2576 \\
\hline $\begin{array}{l}\text { Disabled voters having problems completing } \\
\text { ballot papers }\end{array}$ & 85.7 & 10.2 & 3.8 & .3 & .0 & 2578 \\
\hline
\end{tabular}

Table 4: Accessibility problems at polling stations (\%). Author's data only. 


\begin{tabular}{|l|l|l|l|l|l|l|}
\hline & None & 1 & $2-5$ & $6-10$ & $10+$ & $\mathrm{N}$ \\
\hline $\begin{array}{l}\text { Members of political parties intimidating the } \\
\text { public }^{12}\end{array}$ & 92.7 & 3.7 & 2.8 & .4 & .4 & 5560 \\
\hline $\begin{array}{l}\text { Members of political parties being where they } \\
\text { should not be }\end{array}$ & 91.6 & 5.9 & 2.4 & .1 & .1 & 5677 \\
\hline
\end{tabular}

Table 5: Behaviour of political parties inside polling stations (\%). Author's and Electoral Commission data combined.

\begin{tabular}{|l|l|l|l|l|l|l|}
\hline & None & 1 & $2-5$ & $6-10$ & $10+$ & $\mathrm{N}$ \\
\hline Suspected cases of electoral fraud & 99.3 & 0.6 & 0.1 & 0 & 0 & 5672 \\
\hline $\begin{array}{l}\text { People asking to vote whose identity I was } \\
\text { unsure of }\end{array}$ & 94.0 & 3.9 & 1.9 & 0.1 & 0.1 & 5649 \\
\hline
\end{tabular}

Table 6: Concerns about electoral fraud (\%). Author's and Electoral Commission data combined.

\begin{tabular}{|l|l|l|}
\hline & $\begin{array}{l}\text { Correlation with percentage of } \\
\text { the population that are British } \\
\text { Pakistani /Bangladeshi }\end{array}$ & $\begin{array}{l}\text { Partial correlation controlling for } \\
\text { population density }\end{array}$ \\
\hline $\begin{array}{l}\text { Members of political parties } \\
\text { intimidating the public }\end{array}$ & .033 & .002 \\
\hline $\begin{array}{l}\text { Members of political parties being } \\
\text { where they should not be }\end{array}$ & $.068^{* *}$ & $0.06^{* *}$ \\
\hline $\begin{array}{l}\text { People asking to vote whose } \\
\text { identity I was unsure of }\end{array}$ & $.046^{* *}$ & 0.16 \\
\hline Suspected cases of electoral fraud & $0.03^{*}$ & 0.13 \\
\hline
\end{tabular}

Table 7: Correlations and partial correlations between British Pakistani-Bangladeshi community size and electoral integrity problems. $\quad * * p<0.01, * p<0.05$

\begin{tabular}{|l|l|}
\hline Identity requirements & $\begin{array}{l}\text { Poll workers reporting at least one person asking to } \\
\text { vote whose identity they were unsure of }\end{array}$ \\
\hline None & 4.7 \\
\hline Poll Card & 8.6 \\
\hline Mixed & 6.7 \\
\hline Photo & 6.5 \\
\hline
\end{tabular}

Table 8: Concerns about voter identity, by identity requirements (\%.) Electoral Commission data only.

\begin{tabular}{|l|l|l|l|l|l|l|}
\hline & None & 1 & $2-5$ & $6-10$ & $10+$ & $\mathrm{N}$ \\
\hline $\begin{array}{l}\text { People being turned away because they did not } \\
\text { have the appropriate identification }\end{array}$ & 47.6 & 22.2 & 24.5 & 4.3 & 1.3 & 3155 \\
\hline $\begin{array}{l}\text { People coming to the polling station but } \\
\text { deciding not to vote as they did not want to } \\
\text { comply with the ID verification requirements }\end{array}$ & 76.7 & 18.6 & 3.7 & 0.8 & 0.2 & 3145 \\
\hline
\end{tabular}

Table 9: The effects of the ID pilots on voter turnout (\%). Electoral Commission data only.

\begin{tabular}{|l|l|l|l|l|l|l|}
\hline & $\begin{array}{l}\text { Strongly } \\
\text { disagree }\end{array}$ & Disagree & $\begin{array}{l}\text { Neither agree } \\
\text { or disagree }\end{array}$ & Agree & $\begin{array}{l}\text { Strongly } \\
\text { Disagree }\end{array}$ & N \\
\hline Had little impact on our work & 0.9 & 8.7 & 8.4 & 43.3 & 38.8 & 3179 \\
\hline
\end{tabular}




\begin{tabular}{|l|l|l|l|l|l|l|}
\hline $\begin{array}{l}\text { The majority of voters were } \\
\text { able to provide an acceptable } \\
\text { form of identification }\end{array}$ & 0.1 & 0.1 & 0.7 & 29.0 & 70.1 & 3150 \\
\hline $\begin{array}{l}\text { Voting was more secure } \\
\text { because voters had to prove } \\
\text { their identity }\end{array}$ & 0.4 & 3.1 & 31.3 & 25.7 & 39.6 & 2969 \\
\hline $\begin{array}{l}\text { In my polling station we were } \\
\text { successful in delivering the } \\
\text { voter ID requirements }\end{array}$ & 0.1 & 0.1 & 0.9 & 17.4 & 81.5 & 3174 \\
\hline
\end{tabular}

Table 10: The effects of the pilots on other aspects of the election (\%). Electoral Commission data only. 